\title{
Communicative Violence In Psychotherapy
}

\author{
Michael B. Buchholz \& Marie-Luise Alder ${ }^{1}$ \\ International Psychoanalytic University (IPU)
}

\begin{abstract}
After some theoretical reflections on communicative violence based on the concept of the "double body" (Sybille Krämer) which explains why words can heal or hurt, we show excerpts from therapeutic session using conversation analysis as methodological tool to make subtle forms of violence visible. The problem of violence is not one-sided from therapist to patient but the inverse direction should be included, too. We detect that it is sometimes the "good will" of therapists to help a patient "overcome" a (supposed) "inhibition" to continue talk that contributes to symmetrical escalations in conversation causing trouble in turn-taking. Sometimes it is an up-to-now undescribed practice of patients, which we call "empathy blinder". A mild and a more complex form of this pattern are described. Further examples are analyzed hoping to direct some attention to the problem of communicative violence. In general, we do not yet present solutions, more expositions of a problem widely under taboo.
\end{abstract}

\section{Introduction}

In most cases, and all too soon, the keyword „violence” in the context of psychotherapy triggers that associative connection which views a (female) patient being sexually exploited by a (male) therapist. Then the connection to the public debate on the sexual abuse of children soon drags psychotherapy as a whole into an environment where it can easily or more easily be discredited and scandalised. As a matter of fact, however, since the beginning of the 1980s there has been a wide spread of sensitivity concerning this topic in the field of psychotherapy. Professional associations have established ethics commissions investigating such cases. Members have been excluded from their associations. The book by Phyllis Chesler (1972) had a worldwide impact, for this author, herself a psychotherapist, had interviewed women who had been exploited by their therapists. These narrations were impressive enough to trigger intensive reactions.

Among international psychoanalysis, in particular Gabbard (1994) discussed the topic and described that such incidents happen by a certain sequence: minor transgressions of limits - the session is prolonged, an arm is touched, the hand is held a little bit longer when saying hallo or goodbye - if they are not at once corrected, become the gateway to further steps, such as a more intensive touch, conversations after the session, the use of certain objectionable vocabulary, and thus gradually there develops a cycle of ostensive intimacies, which the patient must find ever more difficult to escape.

${ }^{1}$ Correspondence concerning this article should be addressed to Prof. Michael Buchholz and Prof. Horst Kächele, International Psychoanalytic University (IPU), Stromstr. 2-3.

10555 Berlin/FRG, Germany.

E-mail: michael.buchholz@ipu-berlin.de, marie-luise.alder@ipu-berlin.de

Language and Psychoanalysis, 2015, 4 (2), 4-33

http://dx.doi.org/10.7565/landp.2015.007 
It is no question that under no circumstances such incidents can be tolerated in psychotherapy, the after-effects are devastating, with local educational institutions the effects can be identified as far as in the second and third generations of course participants, and they are catastrophic for the public image of psychotherapy. Fortunately, such cases of misconduct are not as frequent as scandalisation makes us believe, but they are frequent enough. Gabbard (1994) estimates about 10\% of all therapists - from all schools.

\section{Communicative Violence - Basic Considerations}

Making communicative violence a topic of discussion, however, is connected to different problems. Increasingly patients of both sexes, by pointing out to the well-known dangers of being sexually abused, demand psychotherapeutic treatment in the context of which they do not at all want to speak about sexuality. No exact figures are known about this phenomenon. If it is met, such a demand would result in the performance of psychotherapy being extremely limited; if it is not met, this may again be lamented as communicative violence.

Another problem results from exclusively focussing on male violence towards women. Discussing other kinds of communicative violence are found in the surgeries of psychotherapists, how they could be defined and delimited from other operations, proves to be an extremely difficult task, and the reason for this is treatment technique.

These problems are interdependet with other more profound.

In psychotherapy process research during a long period of time data were generated by questionaires, applied from session to session. Finally, it was discovered that not the insession events were observed but another kind of cognitive objects, "opinions about" the session. Hence, we have a debate in what way audio- or videotaped data from session can be sampled and evaluated. The general shift from cognitive objects to conversationalinteractive events of a session generated completely new observations followed by renewed theorizing (Buchholz 2012). Observing kind and length of pauses (Frankel, Levitt et al. 2006), the synchrony of bodily movements (Tschacher, Tomicic et al 2012) or rhythmization of talk (Buchholz, Spiekerman, Kächele 2015) during a session produced new insights in the interactional quality during psychotherapy. One consequence is that it is more and more indeterminable what is meant by psychic violence. It does make sense to talk of communicative violence, as such acts are committed by "talk-in-interaction". The psychic or mental component could be considered as effect of such communicative processes, which remain observable. Thus, another question logically follows. Can and should violence distinguished from aggression?

Two authors exposed some difficulties with the concept of aggression (Bushman and Anderson 2001, Anderson and Bushman 2002). The distinction between "hot" or impulsive and "cold" or instrumental aggression cannot be maintained. It originate from the juridical world where one tried to establish distinctions between different crimes by means of a phase of "cooling down".

I someone reacts aggressively to a severe insult or abasement within a short interval (30 seconds) one could assume that he was under the power of his uncontrollable impulses and this was considered mitigating. Another person, planfully attacking the aggressor 
with a delay of two days should be considered as in full responsibility and, thus, punished more severely. These authors introduce their paper (2001) quoting George Bernard Shaw: "If you strike a child, take care that you strike it in anger, even at the risk for maiming it for life. A blow in cold blood neither can nor should be forgiven".

This quotation illustrates one the one hand the hot-cold distinction convincingly; however, it shows how this distinction is based in mundane thinking and is related to the psychology of reconciliation and forgiveness. It follows, that this distinction is unusable for the motivation or explanation of such acts. The distinction itself survived long in psychology, e.g. in the debate about aggressive drive(s). These authors convincingly conclude that every aggressive act is composed by an expressive-impulsive together with an instrumental component. However, these components cannot be distinguished precisely enough. The distinction itself is not detectable in the events, but in our thinking about events.

The debates about aggression-as-drive produced another blurredness. The concept of aggression serves for both, the designation of something that happens (e.g. when talking of an "aggressive act") and for the explanation of such acts. The result of which are unresolvable circular arguments, when e.g. an "aggressive act" is explained by an "aggressive drive" or "aggressiveness". It is as to explain "having no money" by poverty. It was a release of this circular thinking when Collins (2008) proposed a microanalysis of violent situations; it is discussed with enormous resonance in the social sciences (Aho 2013, Mazur 2009). The basic assumption is the conceptual switch from personality explanations to an explicative situationism. There are describable and observable common features of situations that produce violence. Such components are: If a perpetrator is determined and has the technical equipment available, if the victim is present and weak and if bystanders are either not present or do not intervene. To this schema Collins $(2009,2013)$ adds a crucial emotional component. He observes in numerous examples how humans execute violence with an astonishing amount of incompetence, which is a piece of circumstantial evidence against the assumption of a "drive". Humans do not express anger or rage in their face during fights but anxiety. This tension of incompetence (not being able to hurt) and anxiety (to be hurt) Collins designates as "confrontational tension/fear". To overcome tension/fear needs special trainings. Confrontational tension/fear is accompagnied by a sudden high increase of heart beat unabling untrained people to precisely and welldirected slap or punch an adversary or to use a pistol or gun skillfully. Most people are in an emotional "tunnel" and have to aquire psychological techniques to leave the tunnel in order to execute violence with competence.

A situationist approach could lead further in the analysis of communicative violence. One must not dive into the depth of personality before things are observed and described precisely. In psychotherapy and in process research we seriously lack precise observations rich in details, while the market of original interpretations flourishes. A recent example is the public debate, which kind of diagnosis could be ascribed to the copilot of the Germanwings flight who steered his aircraft with 150 people directly against a mountain in the alpes.

A study to "the pull of hostility" (Lippe, Monsen, Ronnestad et al. 2008) can be assigned to such a situationist approach. Out of a huge pool of transcribed treatments 28 were selected. Every therapist had a successful and a non-successful treatment therein. 14 
therapists were studied this way. The sessions were evaluated in defined segments with SASB2 in dimensions like dominance or response by symmetric escalation strategies. As expected it could be shown that in those treatments where therapists respond to difficult situations symmetrically, e.g. to accusations with accusation or, in a weaker version, with justifications, treatment outcome was bad. However, as the same therapists had positive treatment outcomes, this could not be attributed to a personality trait of the therapist. The authors speak of a dance of escalation. It's powerfulness steers over individual-personal components.

We want to try a situationist approach here without to begin with an abstract definition of violence. We want to present examples that can be considered as having a violent potential and we expect from a rich description of such situations some analytic potentials. We want to analyze these examples in their own right without approaching too quickly to more general considerations.

Readers may allow us to add a further consideration. As humans understand themselves to be autonomous beings, already seeing a person offering help, as the therapist is according to his/her functional definition, is an enterprise that is prone to violation. Krämer (2007) has emphatically underlined man's "double body" in a sense which is of significance here. Not only human bodies may be violated. As human individuals always also operate by way of symbols, move within a cultural period and within a social, not only physical space, they may become interesting and may be desired or being labelled as boring and rejected. They may feel touched and are indeed touched, both by contempt and by being respected and attracting attention; the refusal of respect or even ignoring their personality in the sense of a basal withdrawal of resonance (Buchholz and Gödde 2013) is perceived as a violation - precisely because of this "double body", which may result in a verbal attack being perceived in the same way as a physical attack, triggering appropriate effects. That is why one may feel poisened or purified after a conversation, besmeared or lifted up by contact, hurt, violated or loved by a glane in the other's eyes. It is such elusive moments which we intend to view at here: Moments of the volatile which often escape the perception of others, and later, when we tell what has happened, are rather met with disbelief instead of making us credible witnesses. We do not intend to practice one-sidedness and accuse the therapists right from the beginning, we will also present examples of the violent power of some of the psychotherapeutic patients. This does not mean siding with one or the other side, this is no unstable balance. It is due to the insight how risky the therapeutic enterprise is and that for this reason it is a good thing to have recorded elusive moments, because often they are not really remembered but just brought to mind as a "feeling" by those having been hurt by something they are often unable to determine, after all; sometimes "countertransference analysis" rather obscures than clarifies such moments.

This does not really come as a surprise, as inevitably the way of operating of psychotherapy intervenes, nay, must intervene, in the violation-sensitive field of autonomy, and this while at the same time displaying the virtue of doubtlessly respecting the patient, his/her political or aesthetical opinion, his/her way of life. However, this respect must be balanced by skillfully handled disrespect (Frei, Michel and Valach 2012, 2013). Therapists know that precisely way of life practices are co-responsible for

2 "Structural Analysis of Social Behavior" - a widely used multidimensional circumplex model developed by Lorna Smith Benjamin (1974).

Language and Psychoanalysis, 2015, 4 (2), 4-33

http://dx.doi.org/10.7565/landp.2015.007 
lamented symptoms. Who tries to cope with sorrow by way of eating, to then seek treatment for his/her adiposity, will have to change his/her autonomous way of life to a certain degree; who fights loneliness by way of excessive promiscuity and then gets caught in a thus resulting cycle, cannot be therapeutically helped if his/her implicit "doctrine of the art of living", demanding the satisfaction of every need, is not radically put to question.

Thus we arrive at the question of how far empathy may or is supposed to go? For example, from infant research (Braten 2007) we know that the withdrawal of empathy is experienced as a painful loss but may as well be applied as a means of enforcing obedience or punishment. However, is it not that precisely in therapeutic dialogues there is sometimes the need for a limitation of empathy? Moreover, can therapists always just "accompany" - or are they supposed to - or is it not that they also have the task of pointing out to harmful ways of behaviour, of explaining painful connections, of correcting attitudes that might resist the therapy? Therapeutic understanding requires certain preconditions.

These are the questions we like to discuss here, however we will rather be able to list the problems than to offer definitive solutions. By way of excerpts from transcripts from our own conversation-analytical studies we will discuss therapeutic dialogues (Peräkylä and Antaki 2008); we will not discuss rough, physical forms of violence but only the "small" forms of violent speech that are not even due to the speakers' bad intentions but often to their noble intentions. The violent nature of their speech becomes obvious by the reactions. Thus, we make use of a methodical basic principle of conversation analysis (Schegloff 2007, Sidnell and Stivers 2013). Each statement has its own linguistic form, its function becomes obvious by the "second move", the recipient's answer. This way meaning is created locally and situatively, by each following statement getting its own design, which only makes the second speaker's position understandable for the first one.

We would like to use the same methodical steps - form and function, design and positioning - for those statements by therapists who try to "repair" damage, thus creating an emphatic gain that will be therapeutically helpful again.

\section{Example: An escalation}

Let us look in detail at a German conversation between a male patient and a female psychoanalyst. ${ }^{3}$ It is the beginning of the treatment, the patient tells about his girlfriend who up to then has acted as kind of therapist for him. Here we would like to focus less on the content (why we selected a segment that on first glance seems not understandable) of the conversation but on the way it is organised: who speaks how and after whom? In which way is the break dealt with? Whose is the next conversational move? ${ }^{4}$

P: well. (--) she has well (--) but somehow I couldn't do that to her (--) that was justified, after all, you know it was no exaggeration or so and she didn't (--) she prohibited me from doing it like women do (laughs) that hurts me I don't like that (laughs) you know err (.) well

\footnotetext{
${ }^{3}$ The German original is inserted in italics in order to enable reader to follow the German version

${ }^{4}$ We are very grateful to Christine Reuter, Göttingen, for allowing us to quote this example from her forthcoming dissertation thesis.
}

Language and Psychoanalysis, 2015, 4 (2), 4-33

http://dx.doi.org/10.7565/landp.2015.007 
P: ja. (--) das hat sie ähm (--) aber das ich konnte ihr das irgendwie nicht (--) das war schon berechtigt also das war jetzt nicht übertrieben oder so und sie hat auch nicht (--) sie hats mir verboten wie es Frauen verbieten ((lacht)) das tut mir weh ich möcht das nicht ((lacht)) also ähm $\uparrow$

(15.0)

T: well, she's afraid of losing you,

T: also die hat Angst dass sie sie verlieren könnte,

P: yes, (3.0) that well (9.0) but somehow it is yes she is

P: ja, (3.0) das äh (9.0) doch es ist irgendwie schon ja das hat sie (27.0)

We would like to take note of three particular features of the patient's way of expression:

a) Expressions such as "justified after all" are "intensifiers" of a weak kind. The patient assures himself, as if being in the position of another speaker, of this having been "justified after all" ( similar to the description given in Streeck 2012)

b) As Bergmann observed (1980), the form of the litotes is used also here, to emphasize a different, here: friendly, intention by way of contrasting it to something negative.

c) The many self-corrections after starting to speak and then stopping show multiple speech plans and intentions that violate Grice's maxim of quantity (Grice 1975).

Here there may follow an analysis of form, design and positioning: the analysis of the form shows that the patient speaks from an external position; he speaks while at the same time evaluating his own statements. The design of his statement with its many restarts is hardly addressee-oriented; even when reading slowly one hardly understands what he wants to say. The function becomes obvious by the therapist's reaction. By the patient evaluating his own statements, at the same time he excludes the therapist from conversation. As also Streeck (2012) has described it as a mode typical for anxious patients, he rather talks to himself instead of to an addressee. Finally, this interpretation is also supported by the 15 seconds break after having stopped in mid-sentence.

At the same time, his speech ends with a "starter", this "you know well"; if on this occasion one breathes in and says "you know", one unmistakably indicates the intention to go on accompagnied by a high pitch boundary tone. But this indication to go on talking is contradicted by the long break. The break indicates that the patient gives up on his turn. The multi-modality of the conversation falls apart; the intonation moves upwards, the sentence is not finished - all this indicates an ambiguity if this is a "transition relevant place" (Clayman 2013)? However in contrast the therapist may perfectly understand the long break as being granted the right to speak already now.

This is a situation in which the therapist can only make "mistakes". If taking the turn and starting to speak she reacts to one half of the invitation, by not taking the turn she ignores the other half. This is a typical "slot", from which soon the objection will be raised that the therapist constantly interrupts the patient (Streeck 2001). Here, the therapist takes her turn by immediately connecting to the last spoken word (,well", "also" in German). She speaks as if continuing his words. Doing so, she might believe to have verbalised in a helpful and sensitive way what the patient himself has not yet been able to express. She might believe to have helped with the dialogue. This is also because once again the

\footnotetext{
${ }^{5}$ This much more prominent in the German version.
} 
patient makes a break of 27 seconds that again is introduced by the same contradictious conversation format: an unfinished sentence with a high pitch boundary tone and at the same time a long break. Before going on with this example, we would like to insert a few theoretical considerations.

\section{The "interaction engine"}

One should not shrink back from the expression "interaction engine" as suggested by Levinson (2006); it is not more mechanical than therapists speaking of a "defence mechanism". Often Freud spoke of the "psychic apparatus". Conversation analysts focus most of all on how the exchange between speakers is organised. Observing the organisation of the exchange means taking expression formats as answers by the participants to silent questions, questions such as: "Whose turn to speak is it now?" "Who chooses the next speaker?" "Which topic might suit now?" This way, very pragmatically, conversation partners solve the problem of not constantly interrupting each other. Conversation analysts consider their statements solutions for all questions permeating a conversation.

When Freud (1916) said that in psychoanalysis nothing happens instead of an "exchange of words" (see Scarvaglieri 2013), of course he did not intend to exclude the significance of gestures, gazes, facial expressions but to distance himself from nebulous assumptions that in psychoanalysis there happens a kind of hypnotic mesmerism, a kind of suggestive influencing by help of electro-magnetic powers or something. From Breuer's famous patient, Anna O., he had adopted the expression "talking cure". Indeed, the "exchange of words" has a certain, seemingly rationalist, logic that is transgressed by metaphorical expressions such as "verbal) sparring". That is why Bourdieu (1987, p. 148; 1990), when speaking about G. H. Mead, refers to the latter's remarks on sparring between boxers. For Mead, and Bourdieu follows him there, this practice is really a paradigm of a "logic of practice": each gesture triggers a reaction, "each posture of the opponent" is treated "like a significant sign of a meaning". The logic of practice, says Bourdieu, was used already by Mead for transgressing the limits of an understanding of the "exchange of words" which interprets meaning just hermeneutically. Gumbrecht (1995, p. 136) reminds to Jorge Luis Borges referring to George Bernhard Shaw, by saying Shaw's language was a "reinvention of the Middle Ages", as he was writing a kind of English belonging to the time of Jack Dempsey (then world boxing champion). Boxing serves as a store of images for a metaphor, which is not seldom transferred into the sphere of conversation. Against this background, it does not come as a surprise when Lakoff and Johnson (1980) exemplarily illustrate their then innovative idea of conceptual metaphors by the example of "argument is war". Also in the academic debate, the origin domain of war has often been exploited for metaphorical expressions ("he had to vacate his position") of the more abstract domains.

These considerations can be continued in so far as stating a continuity (Buchholz 2011) from particularly the interaction of the child, which is dominated by gestures (Braten 2009), and its continuation as far as to using linguistic symbols. As it is well known, Mead adopted from Wilhelm Wundt "language as gesture". Modern cognition-theoretical works on enactivism (Di Paolo, Rohde, Jaegher 2011), on extended mind (Menary 2011), on embodied cognition (Shapiro 2011) take their innovative nature precisely from vehemently distancing themselves from earlier, still modularistic or genetic concepts of "cognition". Thinking and speaking are considered to be embodied (for psychotherapy 
see Buchholz 2014), the earlier computer metaphor of mind is considered to have been overcome. "Embodied interaction" (Streeck, Goodwin, LeBaron 2011) might be considered the perspective which, when it comes to the "exchange of words", is indeed able to take "sparring" into consideration, thus raising our awareness of violations by words in a way as Krämer has described it by the term "double physicality" (s. a.). However, if "trouble" occurs and one interrupts each other, there is a wide range of "repair activities" (Egbert, Golato et al. 2009, Kitzinger 2013, Sidnell 2007), which appear regularly and in an interculturally stable way as a conversational practice for each exactly describable situation (Stivers, Enfield et al. 2009). If these repairs do not work, "trouble" increases to become a serious problem - on the form and function of these repairs as well as on their failure we will soon say more.

Levinson (2006) shows how important the "interaction engine" has become in the course of evolution. Humans are very much both dependent on cooperation and particularly capable of it. The "interaction engine" makes sure that an expression has been heard and is answered as such (and not just as a kind of "noise"), that an indicating gesture has been followed by a look, that a cry has been heard as coming from need and not just as a kind of noise. Gradually, interaction was organised around cooperative principles.

Purposefully, Levinson speaks of an "interaction" and not of a "conversation engine". Even if humans - such as aphasics - have only extremely reduced possibilities of conversation and one can hardly make conversation with them, interaction is definitely possible (Jakobson 1955, Goodwin 2000 und 2012, Heschen und Schegloff 2003, Mellies und Winneken 1990). This is the case even if humans cannot use sounds but must refer to spontaneous sign language - in case of speaking foreign languages, of being behind a window, or over distances.

Organising interaction around cooperative principles includes answering not to a speaker's (visible) behaviour but to his/her invisible, initially short-term intentions and later long-term plans, and later still to images. "Interaction is by and large cooperative" (Levinson 2006, p. 45). Interaction produces chains and sequences that can be learned by any novice to a culture and which make it easier to reliably predict the behaviour of others. The decisive step is: Such chains and sequences are not based on abstract rules but on situative and local expectations. Thus interaction does not depend on language, as expectations and intentions may be secured also in a non-linguistic way and by way of cooperation. Interaction is "deeper a layer" than talking. Interaction creates actual and local roles in the context of situated, contextual production, pairs of roles such as "inquirer-answerer", "giver-receiver". These pairs of roles are determined by mutual expectations, so that there develops an interaction structure that is sufficiently stable for the solving of cooperation tasks.

This stability is created by momentarily binding individual gestures to accompanying verbal expressions, facial expressions and prosody (Couper-Kuhlen and Selting 1996) all this is bound up to a multi-modal stream of signals. The components of this bond are expected to fit together to a large degree, because otherwise a listener would not be able to safely understand the speaker's intention. There is a physical basis for such an attachment (Franke 2008, Vuust, Wallentin et al. 2011, Dausendschön-Gay und Krafft 2002). 


\section{Back to the example}

After these clarifications we may come back to the example, and now we at once realise the problem. By his unfinished sentence the patient makes obvious that he would like to go on speaking; however the long breaks contradict this expectation, they irritate the therapeutic listener: is she allowed to say something now? The conversation channels are not "bound together", in the sense that the therapist could expect clearly decipherable intentions from the patient. Is this a "transition relevant place" (TRP, Clayman 2013), in the sense that the therapist being allowed to say something without causing "trouble"? Is it her turn now or not? This pattern is repeated immediately after this passage:

P: well, this may be you know I think it is still too fresh (--) to say so But $\uparrow$

P: ja, das kann sein also das ist jetzt glaub ich noch zu kurz (---) um das sagen zu können aber $\uparrow$

(6.0)

T: but still this could (--) the thought just came to me if this well somehow I'm not saying (-) frightens Anny but isn't doesn't (.) simply pleasure (.) a pleasure for her. T: aber trotzdem könnte diese (---) war eben so mein Gedanke ob das nicht äh bei Anke ein bisschen ich will nicht sagen Angst macht aber doch nicht nur nicht nur erf Freude macht.

Once again, the patient does not finish a sentence, once again he makes a longer break, thus inviting his conversation partner to speak, although he leaves his sentence unfinished. Once again it stays unclear if this is a transition relevant point. And once gain the therapist continues by going on with the patient's last word, "but".

"Speaker's turn-internal breaks" (Schegloff 2007) are found with many dialogues, here you get the described form. Just a few dialogue sequences later, and we see how the session escalates:

P: well I don't try to connect this to any kind of rivalry but (--) well I do perceive it if for example he somewhat gives expression to it you know (--) I think last time I told you about the weekend ten days ago (-) when the two really freaked out well () well $\uparrow$ P: also ich versuche da keinerlei Rivalität rein zu bringen aber (-) äh ich nehme das schon wahr wenn das von ihm so zum Beispiel mal ein bisschen kommt also (-) ich hab glaube ich das letzte mal erzählt von vor zehn Tagen das Wochenende (-) da wo die beiden sehr stark ausgerastet sind so (-) äh $\uparrow$

(4.0)

P: then (-) I somewhat thought he really wants to know what's going on or somehow he wants $\uparrow$ da (-) hab ich schon so ein bisschen gedacht er will schon wissen was los ist oder er will irgendwie $\uparrow$

(6.0)

P: well yesterday (-) yesterday the day before yesterday? We went to the hockey match on the car because now the two wanted to see and they came along a:nd (-) I was sitting in the frontseat and took my arm around her (-) well seat and that was when from behind there was this little knock you know [ (?? )] $\uparrow$ ja gestern sind wir mit dem (-) gestern, vorgestern? gestern sind wir mit dem Auto 
äh zum Hockey gefahren weil die beiden jetzt auch mal gucken wollten und sind da mitgefahren u:nd (-) äh da hab ich (.) saß ich vorne und hab den Arm um *Name* (-) ähm Sitz gemacht und da kam von hinten so ein kleiner Klopfer also [(??)] $\mathrm{T}$ :

[ (??)]

$[(? ?)]$

P:

[ (??)] leave my wife alone

[(??)] gehn Sie weg von meiner Frau

P: well, (2.0) well you know I'm sure he didn't mean it but from his side it was kind of a game ( ) that $\uparrow$

P: nja, (2.0) äh also von ihm her sicherlich nicht bewusst sondern es war so von ihm her so ne Art spielen ( ) das

$\mathrm{T}: \mathrm{mmh}=\mathrm{mmh}$

Although the patient did not intend to make this "kind of rivalry", nevertheless it is suddenly there: the spare brackets mark where there happens a fight for the right to speak $^{6}$ which could not be identified when many times listening to the tape. Both conversation partners are starting to say something, but only very shortly, each intrudes the other's speaking space, and then the rivalry, which was to be prevented is staged by the organisation of the conversation. The space of speaking, that is the metaphorical container "into which" rivalry is introduced.

Here, the therapist's expression formats take up the form of "quasi quotations" (Buchholz 2003). She speaks as if quoting the patient, as formulating for him, formulating what he is as yet incapable of saying. However, by this helpful attitude she overlooks that all she can do is ,wrong": either she follows the hints that the patient wants to go on speaking or that she shall take her turn - either way the patient could then accuse her of not having "understood" him. Taking turns of speaking is organised in a highly ambivalent way here. Thus, inevitably the therapist will be blamed, blamed for intruding into the space of speaking, for seemingly unjustifiably usurping the right to speak, which is why one is entitled to take it from her in the course of a small, escalating fight for the right to speak, and she will have to admit her guilt, for it was her who "started it" - at least this is the way the patient understands the situation. (Streeck 2001 makes a related observation.) Here precisely the helpful attitude contributes to the clash.

\section{Example: Autonomy-sensitive repair}

Our next example comes from a psychoanalytical first interview with a compulsive neurotic patient, called the "student" (Thomä and Kächele 1985). In the first minutes the

\footnotetext{
${ }^{6}$ Schegloff (1987, S. 207) starts his explanation of social organization by way of „talk-in-interaction” by the following description: „When persons talk to each other in interaction, they ordinarily talk one at a time and one after the other. When their talk is not produced serially in this manner, they generally act quickly to restore ,order'; someone quickly steps in to fill the silence; someone stops talking (or several someones do) to resolve the simultaneous talk; or if two or more of the participants continue talking, their talk takes on a special character of ,competitiveness' (it is louder or higher pitched, for example)". This fight for the right to speak, this "competitiveness” is the boxing match Bourdieu (2007) refers to.
} 
patient had expressed his guess that his compulsive acts might be due to the fact that as a child, when playing in the woods, he had been locked into a log pile by other children and that they did not let him come out. Shortly after having told this experience he takes off his jacket, and while he does so there develops the following conversation sequence which we would like to analyse at first as such and then in a wider context:

T: !ALREADY HERE! you have even (1) .hhh almost felt boxed in?

$\uparrow$ right now? and then you took off that jacket?

T: HIER HABEN Sie sich auch schon (1) .hhh fast eingeengt? gefühlt? $\uparrow$ gerade? und sich dann die Jacke ausgezogen?

P: pfff boxed in? I think it was rather the heat yes indeed (.) sure= P: pfff eingeengt? I glaub das war eher die Wärme ja doch (.) klar=

The conversational operation performed by the therapist here is precarious. It consists of three different components: a) cognitively connecting - by the particle "even" - the situation of feeling boxed in, as it was told as a childhood experience, with being boxed in by the actual conversation situation; b) connecting a confrontative reproach with a visible behaviour during the session, that is taking off the jacket; c) constructing a motivation, the claim that the patient had "almost felt boxed in", which is formulated while the voice is getting louder.

Already in 1932 Alfred Schütz (1932/1973) had distinguished between "for the purpose of" and "because" motivations which are a constant element of everyday conversation. In the Lebenswelt the teleological formulation ("for the purpose of") is not illegal, it coexists with the causal motivations of "because". However, it is conspicuous that such attributions of motivations are almost always made only while referring to oneself. If they address somebody else, Schütz found out, in most cases such attributions of motivations come along with a negative addition ("You are doing this only because ..."). Attributing a motivation to somebody else, even more if he/she is him/herself not aware of it, is a conversation-technically very precarious enterprise. Usually such a construction of a motivation is rejected because it is perceived as an interference with my autonomy; it seems as if the conversation partner knows better than I the motivations which have driven my behaviour.

On the other hand, working out a previously I-alien motivation is a so to speak exemplary description of the task of "uncovering therapy". The therapist is almost obliged to present such constructions of motivations, and he/she expects to be rejected, which is due to the patient's need of autonomy. In so far, being told why one has just taken off one's jacket is a "disrespectful" intrusion into a patient's sphere of autonomy - and he/she will react by rejecting it, by adding a motivation of his own, may it be the heat. If this is a rationalisation in the clinical sense must be left open here. We note that in this sequence it is the patient who is said to be motivated by feeling boxed in.

Here, the entire context of the sequence. The patient tells about his newly started studies, which he has started after having dropped out of his law studies:

P: an:d there I have many different subjects, (.) that is already (.) quite positive for me if I don't have to always concentrate on one, well?= 
P: un:d da hab ich also viele verschiedene Fächer, (.) dis is schoma (.) für mi ganz positiv wenn $i$ net immer auf öin so rumreite muss, gä?=

$\mathrm{T}$ : $=\mathrm{hm}=$

P: subjects; (.)

=excessive, (-) I've also got many well ehm pleasant

=exzessiv, (-) $i$ hab auch viele äh angenehme Fächer; (.)

T. yes:?

$T: j a: ?$

P: like (.) what I do I know, many sports things also, (.)

$P$ : so (.) was weiß ich viele sportliche Sache auch, (.)

$\mathrm{T}: \mathrm{hm}$,

$T: h m$,

P: a cooking class and, you know, like media education subjects;

$P: n$ Kochkurs und halt so Medienpädagogische Fächer;

$\mathrm{T}: \downarrow \mathrm{hm}$,

$\mathrm{P}:$ and that: is quite good for me after all (?)= P: und des: tut mir eigentlich ganz gut (?)=

$\mathrm{T}:$ $=$ this is where you can better unfold your talents

$\mathrm{T}: \quad=$ da können sie sich dann mehr entfalten

P: yes:,

P: ja:

T: then law paragraphs don't make you feel (---)

T: da werden sie nicht durch Paragraphen so (--)

P: boxed in yes (-)

P: eingeengt ja (-)

T: !ALREADY HERE! you have even (1) .hhh almost felt boxed in? $\uparrow$ right now? and then you took off that jacket?

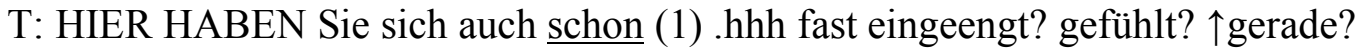
und sich dann die Jacke ausgezogen?

P: pfff boxed in? I think it was rather the heat yes indeed (.) sure=

P: pfff eingeengt? I glaub das war eher die Wärme ja doch (.) klar=

$\mathrm{T}:$

$\mathrm{T}$ :

$={ }^{\circ}$ yes? ${ }^{\circ}$

$\mathrm{P}:=$ conveyed like [this

$={ }^{\circ} \mathrm{ja} ?^{\circ}$

$\mathrm{P}:=$ vermittelt auch irgendwie [so

T: $\quad$ [indeed? yes, hm;

T: $\quad$ [ja? ja, hm;

(1)

T: really? really? I !WELL! I could imagine that the room, you know;

T: so? so? I MEI i könnt mir vorstelln das so der Raum:,

$\mathrm{P}$ : well it is (.) quite small yes

$\mathrm{P}$ : der is scho (.) ziemlich klein ja

T: !SMALL! (-) I thought so: that you've got this feel[ing

T: KLEIN (-) dacht ich so: dass sie das Gefühl gekriegt hab[n

Language and Psychoanalysis, 2015, 4 (2), 4-33

http://dx.doi.org/10.7565/landp.2015.007 
P:

[but this hasn't got we ha h with

claustrophobia [it might even be smaller I wouldn't [mind

$P$ :

[aber mit Platzangscht hat des ja

ha h aber nicht [s also der könnt auch noch kleiner sein des würde mir [nichts ausmache

$\mathrm{T}: \quad[$ no

T: $\quad$ [nein

[yes, yes, no; bu:t; (-) maybe cramped;

[ja, ja, nee; a:ber; (-) vielleicht eingeengt;

$\mathrm{T}:>\underline{\text { Oh this }}<(-)$ is a feeling I've got (.)

$T:>\underline{A h d e s}<(-)$ is a Gefühl von mir (.)

P: hm (-)

P: hm (-)

$\mathrm{T}: \mathrm{i}: \mathrm{f}$ this:: is important that you take care if you feel cramped,

T: o::b das:: das wichtig wäre dass sie darauf achten ob sie sich eingeengt fühlen,

P: .hh perhaps I've i:gnored that much too long (.),

$P$ : .hh des hab $i$ viel zu lang (.) verna:chlässigt,

The development of the autonomy-sensitive construction of a motivation becomes clearly visible if one notices how the therapist at first confronts the patient with the statement that he had "almost felt boxed in". The statement is qualified by the word "almost" which serves for creating a soft conversational environment. He does not only use a soft formulation in form of a question for his construction of a motivation but audibly rises his voice (indicated by $\uparrow$ ) when saying that word which is supposed to link the current situation with the just mentioned one: "right now". This might indicate that he is aware of the precarious confrontation. His rejection of the patient's attribution of a motivation, who just the same presents an alternative motivation, "heat", makes the therapist step by step retreat to his original position, however he maintains his attribution of a motivation as a situative assumption. At the end of this section it is the therapist who says: "maybe cramped. Oh this is a feeling I've got". It stays communicatively unclear if here the word "feeling" means "this is the impression I've got" or if his "feeling" already refers to the then following recommendation, that is if it was important for the patient to take care of this feeling of being cramped. Such communicative vagueness has often been observed with conflict communication (Donnellon, Gray et al. 1986, Donnellon 1996). Here vagueness refers to the speaker's perspective, thus getting a hidden meaning: The feeling of being boxed in, which initially is clearly attributed to the patient, is now revoked; the therapist so to speak admits a mistake, without clearly saying so - and the patient can be "satisfied" with this and can now himself continue with the remark that he had "ignored this much too long".

\section{The Correction Engine}

In the above quoted paragraph there is another autonomy-sensitive construction. The therapist's construction of a motivation, which has proved to be wrong, is understood by the patient, again erroneously, in the sense of the therapist suggesting "claustrophobia" as diagnosis, to which once again he reacts by being slightly irritated, to then react by a clear, although incomplete, rejection "but this hasn't got ha $h$ with claustrophobia" - one must complete this by inserting "to do". This correction is important for the patient because without such a correction he would have the impression of "not being understood 
correctly", which would give reason to the fear that without such a correction he would not provide the therapist with the necessary hints for a "correct" understanding of his disturbance. The therapist confirms this correction by a "no" - also here we may complete: "this hasn't got to do with claustrophobia".

The form of such a correction by the therapist has two functions:

a) The therapist reacts in an autonomy-sensitive way and revokes his statement when the patient indicates his irritation.

b) Revoking is itself an active information telling the patient about the therapist's "positioning"; i. e. that the latter is ready to respect the patient's autonomy and will indeed not authoritatively enforce options for an interpretation.

Both from empirical infant research and from the observation of mother-infant dialogues (Corrin 2010) we know quite well that by far the biggest share of everyday interaction with small children consists of such "repairs". Sometimes mothers do not understand their children's intentions and correct their own activities only after the children have continued to state their discontent. An appropriate interaction cycle may be understood as a contribution to developing a "sense of autonomy"; Emde (1988) was the first to point out that here, already at a prelingual state, there develops a mode of "relationship-onrelationship" conversation which in the realm of developed linguality would be called a "commentary". In the field of social-psychological game theory, already Morton Deutsch (1958) pointed out that even under communicatively extremely restricted conditions, when the players may only make a few moves without seeing or speaking to each other, one tries to deliver such silent messages to be able to inform the other about one's own intention to go on with playing cooperatively or competitively. This finding suits perfectly here; repairs are no "mistakes" but itself important means for an autonomysensitive conversation in a therapeutic context.

Such an analysis moves at the topical-semantic level, leading to mutual attributions and their corrections and proneness to mistakes. It shows how both participants continuously work on informing each other about their mutual positions as speakers, in a way which make the statements make sense, so that the heard meaning of the information can be ratified within a certain range of tolerance by the expressed intentionally stated meaning. Granted, each statement may be understood "in this or this way"; to make conversation progress, every speaker must be able to be sure that a certain range of agreement is not left or is at least corrected on time. Here we see how one correction is so to speak swapped for another one. We assume that the "correction engine" works on the basis of those principles as above described for the "interaction engine".

\section{Example: Intrusion}

The following example comes from the $152^{\text {nd }}$ psychoanalytical session of patient Amalie, about which Thomä and Kächele have informed in detail in the second volume of the Ulmer Lehrbuch. The session under consideration here has already been analysed on several occasions (Erhardt, Levy et al. 2014; Kächele, Thomä 2003; Deppermann, Lucius-Höhne 2008; Kächele, Albani et al. 2006). These studies are based on the Ulm Transcription (Mergenthaler and Kächele 1988) which, however, has proven to be in need of correction in several respects when listening once again to the audio recording, which is why here we quote from a new transcription according to the GAT standard (Hepburn and Bolden, 2013). So much on the context of the here presented section: 
The patient suffers from so called hirsutism, that is male body hair, which can hardly be treated medically, and cosmetically only with much effort. In despair, she had joined a monastery but then left it again to become a teacher. Then she had heard about the possibilities of psychoanalytic treatment. In the course of this treatment she gains so much self-confidence and courage that after some time she starts her first sexual relationship with a man, in the context of which she discovers bodily enjoyment. She starts the $152^{\text {nd }}$ session by telling about a dream about which much has been written. She dreams that a black man is about to stab her with a knife from behind, and in this situation her skirt had moved up. Full of fear she had woken up.

While, when telling this dream, she seems to be the victim of male aggression, the tide is turning; in the course of the session she more and more develops an urge to intrude the analyst's head. She wants, as she emphasizes by rhythmically spoken words (see Buchholz, Spiekermann, Kächele 2015), to intrude the analyst's head, and when expressing this desire she colourfully changes between the metaphorical and the material meaning of the word "head". It is not at all that she just wants to intrude her analyst's "mind", but definitely she actually means the head. She remembers an "old story" of her father who, she says, had always been too soft:

P: it's a really old fear (3) that you can't stand it you know my father never stood [anything (2) you wouldn't believe how soft my father [is $P$ : is ne ganz alte Befürchtung (3) dass Sie's nicht aushalten mein Vater hat ja nie was [ausgehalten (2) Sie glauben gar nicht wie weich mein Vater [ist $\mathrm{T}$ [yes: $[\mathrm{mhm}$ T: $\quad[\mathrm{Ja}:$ $[\mathrm{mhm}$

(2)

$\mathrm{P}:$ He didn't stand anything $=$ $P$ : nix hat der ausgehalten $=$

T: $\quad=$ but then, it is even more important if my head is still really hard! This will indeed increase h::ow (1) well (.) >strong you will grasp $<$. T: $\quad=$ aber umso mehr ist dann wichtig ob mein Kopf noch wirklich hart ist! Das steigert ja dann auch di::e (1) äh (.) > Härte des Zupackens $<$. $11 \mathrm{P}: \quad \mathrm{hhh}$.

$\mathrm{T}$ : F:or if it is hard then you must still:: then it is easier to find out (.) yes! How hard is it now, after all, isn't it?

T: de:nn wenn er hart ist dann muss man ja noch:: dann kann man ja eher aus=raus (.) kriegen ja! wie hart ist er nun, nicht wahr?

P: ${ }^{\circ}$ yes $^{\circ}$ yes and you can grasp more strongly and $=$ $P:{ }^{\circ}{ }^{\circ}{ }^{\circ}$ ja und man kann härter zupacken und $=$

$\mathrm{T}:$

$T:$

$\mathrm{P}$ :

$P$ :

$\mathrm{T}:$

$$
\begin{aligned}
=\text { exa:ctly } & \\
=\text { Gena: } u & = \\
& =\text { Yes } != \\
& =J a != \\
& =\mathrm{mh} \mathrm{mh} \mathrm{mh}
\end{aligned}
$$


P: and you can better (1) fight with the knife

$P$ : und kann besser (1) bis aufs Messer kämpfen

Here the participants do not understand the knife to be a sex symbol, as might be suggested by a primitive reading of psychoanalysis, but definitely the patient connects it to her dream as an offensive weapon. However, whereas when telling her dream she passively fears the knife, here she changes her position. Her desire for a father who could stand something is not only accepted by the therapist but he offers himself so to speak as a "sparring partner" (from line 7 on). A few sentences later she wants to intrude the therapist's head, when saying that sometimes she also sees other people and looks at their heads:

P: really very bad! Then I yes= and measured other heads

P: schon ganz schlimm! Dann bin ich ja[=und hab andere Kö[pfe vermessen

$\mathrm{T}:$

[YES $\quad[\mathrm{mm} \mathrm{mm} \mathrm{mh}$

$T$

[JA

[ $\mathrm{mm} \mathrm{mm} \mathrm{mh}$

P: I did this (1) perhaps during my studies sometimes (-) then I had such a time

P: das hab ich (1) vielleicht im Studium mal getan [(-) da hatt ich so ne Zeit

$\mathrm{T}$ :

$\mathrm{T}$ :

[Yes

Yes

$[\mathrm{Ja}$

$\mathrm{Ja}$

P: and now it happened again (..) indeed triggered by you

P: und das kam jetzt auch wieder (..) eben durch Sie ausgelöst worn

$\mathrm{T}:{ }^{\circ} \mathrm{hm} \mathrm{hm}{ }^{\circ}$

$\mathrm{P}$ : and THEN! $=\mathrm{I}=$ want=to QUITE (.) a small (.) hole in the head (.) in the

P: und DA =will=ich=so ein GANZ (.) kleines bißchen (.) $n$ Loch in den Kopf (.) in den

T: $\quad{ }^{\circ} \mathrm{mhm}^{\circ}$

P: Head! Hammer in the head $()=$.

P: Kopf! In den Kopf (.) schlagn=

$\mathrm{T}:$

$=\mathrm{mhm}$ yes $=$

$T:$

$=m h m$ ja $=$

$\mathrm{P}:=$ and put some of $=\mathrm{of}^{\circ} \mathrm{my}$ thoughts into it ${ }^{\circ}{ }^{\circ} \mathrm{like}^{\circ \circ}$. This came to me

$\mathrm{P}$ :und da ein bißchen was von $=$ von ${ }^{\circ}$ meinen Gedanken rein $\operatorname{tun}^{\circ}{ }^{\circ} \mathrm{So}^{\circ \circ}$. Das kam mir

$\mathrm{T}: \mathrm{mhm}$

P: the other day (..) if I could not somewhat exchange YOUR=dogma (.) for MINE P: neulich (--) ob ich nicht ein bißchen IHR=Dogma (.) gegen MEINS austauschen kann

$\mathrm{T}: \quad \operatorname{mhhhh} .=\mathrm{mm}(($ rising voice $))$

$\mathrm{P}: \mathrm{Li}=\mathrm{ke}(.) \mathrm{li}=\mathrm{ke}(.) \mathrm{hhh} . \mathrm{Li}=\mathrm{ke} \mathrm{I}{ }^{\circ}{ }^{\circ} \mathrm{can}^{\circ \circ}{ }^{\circ}$ imagine you (-)

P: So=wie [(.) so=wie [(.) hhhh. So=wie Si::e (3) ich mir ${ }^{\circ}$ vorstellen ${ }^{\circ}$ kann $^{\circ \circ}$

$\mathrm{T}: \quad$ Yes $\quad$ Yes

$\mathrm{T}: \quad[\mathrm{Ja} \quad[\mathrm{Ja}$ 
P: (-) putting your dogma (1) into mine

P: (-) Ihr Dogma in meins (1) rein zu tun

(2)

P: and then the head found it easier to say than

$P$ : und dann ging es mit dem Kopf leichter zu sagen als

(2)

T: $\quad$ Yes

T: $\quad J a$

P: $\mathrm{I}^{\circ \circ}$ said $^{\circ \circ}$ to myself already on (2) Wednesday (1)

P: ich hab's mir schon am (2) Mittwoch [(1) ${ }^{\circ}$ gesagt ${ }^{\circ \circ}$

T:

$[\mathrm{mhm}$ And then also $=$ also the

intensification of your idea of joining a monastery would be a possibility to challenge me for a fight

$T$ :

[mhm Und dann wäre auch=wäre

auch die Intensivierung Ihres Gedankens ins Kloster zu gehen eine Möglichkeit

mich herauszufordern zu einem Kampf

$\mathrm{P}: \underline{\mathrm{mhm}}$

T: to (.) for a fight which also (.) during which then you wo=uld be GRASPED (.)

T: um Sie (.) nämlich zum Kampf der auch (.) bei dem Sie dann FEST=gehalten wür $=$ den (.)

P: hhhh.

T: not $=$ only be grasped (.) GRASP and try how how $>{ }^{\circ}$ how $=$ much $=\mathrm{I}=$ can $=$ stand $^{\circ}<<$ T:nicht=nur selbst (.) FESThalten und ausprobieren wie wie $\left[>{ }^{\circ}\right.$ wieiviel $=\mathrm{ich}=$ aushalt $\left[\mathrm{e}^{\circ}<<\right.$

P: $[$ hhhh. P: [hhhh

[ Yes

$\mathrm{T}$ : but that then FINAlly! (1) during that fight I show how!=much I'm (.) interested! in you (.) NOT joining the monastery [but

T: sondern dass ich dann auch ENDLich! (1) in dem Kampf zeige wie!=sehr mir (.) daran=gelegen ist! dass Sie (.) NICHT ins Kloster geh[en sondern=

$\mathrm{P}$ :

[to my mother

$P$ :

[zu meiner Mutter

$\mathrm{T}:=$ remain staying

$T:=$ der Welt erhalten

P: oh yes probably indeed

P: ohja wahrscheinlich schon

$\mathrm{T}:=$ in the world

T: bleiben

The passage which belongs to the context of communicative violence is the one where, repeating it three times and with rhythmic accentuation, she says this:

P: and THEN! $=\mathrm{I}=$ want=to QUITE (.) a small (.) hole in the head (.) in the

T: $\quad{ }^{\circ} \mathrm{mhm}^{\circ}$

Language and Psychoanalysis, 2015, 4 (2), 4-33 


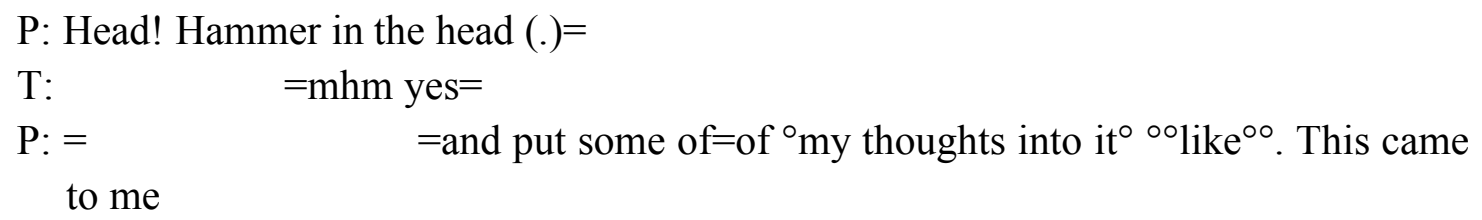

Doubtlessly, such statements by the patient, if we take them out of their context, indicate a tendency towards violence. The ways in which the therapist makes his statements, however, provide the patient with access to this violence, which in her dreams she still perceived as a threat, as a realm of her own activity. Quite obviously, in the case of Amalie the therapist considers himself an active participant in the process, tailoring his statements in a way enabling the patient to indeed listen to them as being processgenerated. Here, the therapeutic statements are no previously readymade "interventions" into a "problem".

The conversation solves an important problem: on the one hand, people see the therapist because of disturbances which are classifiable as illnesses/disorders and expect him/her to know a way of healing or alleviating them. On the other hand, treating the patient in such a way, categorically considering him/her most of all a "case of ... (fear, depression, obsession)", might make any therapeutic effort a failure right from the beginning. Precisely concerning his/her individual uniqueness and particularity, the patient would have the impression to be missed as a personality. Here, the process-generated formats of therapeutic statements solve the problem in an elegant way. They apply a form which presents itself less as advice or initiative but may rather be understood by the patient as an in each case conversational answer to that what she makes a topic of discussion. She may feel to be perceived as a unique individual, not as a "general case" - and that is an autonomous-sensitive therapeutic activity.

The patient, on the other hand, opens up access to meanings and accepts them to be opened up by the therapist who at the end of the passage mentions that the patient would like to see him in a certain position - as the one demonstrating that he is interested in her. By the hint that he might not want her to join the monastery but to stay in the world, the topic of love and sexuality is gradually prepared.

Here, the co-construction of the emphatic process can be reproduced in detail. The therapist's accompanying, richly modulated prosodic statements will be observed in more detail in the course of a later analysis; their form seems to have most of all the function to tell the patient that the therapist is not afraid. Here, his lack of fear becomes a condition for violence to change; it is very beautifully demonstrated how violence could be a conversational co-construction in which a therapist could participate in the one, or indeed the other, way. This other way has always be called empathy, which can be observed here as a position working against violence to develop. Let us now move to another example, where empathy is mildly "blinded", to move from there to the example of a strong communicative empathy blinder operating like a "flashbang".

\section{A mild empathy blinder}

More recently, also the development of theory has caught up with that what was practiced by psychoanalysis already in the early 1970s. The discovery of mirror neurons (Ferrari and Gallese 2007; Gallese and Goldman 1998) provided important stimulations in this 
context, just as the debate on the Theory-of-Mind Theory (Stueber 2006, Breithaupt 2009, Breyer 2013). One might say that the common focus of criticism of this research is on empathy having previously been understood as a "one way street". The experimental designs were made in such a way as to hardly allowing for emphasizing that for the emphatic party it is as important to get a correct understanding as it is for the one who is understood (Schlicht 2013). Empathy is not an epistemological but a mutual process of existential commitment, among whose means there also counts musicality (Buchholz 2014). Also for the therapist it must become important that his patient understands him when he is trying to understand her.

Thus, empathy as a jointly created communicative process replaces any theory of empathy being a "one way street", with one party, by help of particular skills, empathizing with the other. Rather, empathy is understood to be a conversational coproduction jointly developed by the participants in the conversation. Heritage (2011) describes such co-productions in everyday conversation and demonstrates either strategies of the participants to, in a variety of ways, make others adjust to their narrations or strategies of reacting to certain narrations. For example, one such conversational strategy, that of "ancillary questions", describes interested questions which obviously serve the purpose of enabling the listener to get an appropriate idea of that what is told; another strategy are those "response cries", already described by Goffman (1978), by which one reacts if one is told about the painful procedures at the dentist.

Such everyday patterns can be identified also during therapeutic conversations, however they give only an incomplete description of the emphatic overall architecture of therapeutic sessions. Thus, here we would like to give an example of a patient making it really difficult for the therapist to comprehend a situation he is told. Strictly saying, this might even be called "empathy blinding". If empathy is seen as the antipode to violence, also such examples belong to the context of communicative violence.

Also the here presented sequence comes from the first therapeutic session of the Ulm "student". After a short welcome, the patient starts telling the therapist about his symptoms. He describes his obsession by the following words:

P: [ (Well you know] =behaviour you know like control obsession (..) and when like (.) for example (.) I step out of the front door (.) $>$ not then $<$ but when I enter [then I have a look

$P:[(j a$ so $)]=$ verhalten also so Kontrollzwang (--) und wenn i ja so (.) zum Beispiel

(.) aus der Haustür rausgeh (.) $>$ dann net $<$ aber wenn ich reingeh [dann guck ich $=$

$\mathrm{T}:$ [hm: $=$ yes

T: $[\mathrm{hm}: \quad=j a$

P: at the back=

$P:$ nach hinten $=$

$\mathrm{T}: \quad=$ yes

$T:=j a$

P: and I check if I have not forgotten anything or so

$P$ : und kontrolliere ob $i$ auch nichts vergesse hab oder so 
The patient tries to describe his control obsession by way of an exemplary situation: "and when like (.) for example". This announcement is followed by an image, that he "step[s] out of the front door". After a micro-pause there seems to follow a correction and a new image of his attempt at describing the situation, when he "enters" through the front door. In this context, the correction of the first image or the negation of the first example, "not then", is placed in such a way that it is presented only after a micro-pause and immediately following the next image. Here develops irritation, due to the vagueness of the presented image and the thus intended invitation to be literally able to visualise his symptoms: it cannot be decided if his control obsession is demonstrated by the example of leaving or entering the house. This mismatch or incongruence of presented intention and action and the thus resulting irritation is impressively described by Greenspan and Shanker (2007) as well as Buchholz (2014).

The form of this ambiguous format of expression has a function, the therapist reacts in a slightly irritated way, the further sequence from the conversation shows his efforts to get an appropriate image by help of the "ancillary question" - and his failure:

P: [ (Well you know] =behaviour you know like control obsession (..) and when like (.) for example (.) I step out of the front door (.) $>$ not then $<$ but when I enter [then I have a look

$P:[(j a$ so) $]=$ verhalten also so Kontrollzwang (--) und wenn i ja so (.) zum Beispiel

(.) aus der Haustür rausgeh (.) $>$ dann net $<$ aber wenn ich reingeh [dann guck ich $=$

$\mathrm{T}:[\mathrm{hm}: \quad=\mathrm{yes}$

T: $[\mathrm{hm}: \quad=j a$

P: at the back=

$P$ : nach hinten

$\mathrm{T}: \quad=$ yes

$T:=j a$

$\mathrm{P}$ : and I check if I have not forgotten anything or so

$P$ : und kontrolliere ob $i$ auch nichts vergesse hab oder so

$\mathrm{T}$ : if you enter through the front [door

T: wenn Sie reingehen in die Haustü[re

$\mathrm{P}:$

[Yes when I leave it is not=

$P$ :

[Ja wenn ich rausgeh net=

$\mathrm{T}:$ $=$ then you check what;

$T:$

=dann: kontrolliern Sie was;

P: well, what, you know .hh

$P$ : ja was, also .hh

$\mathrm{T}$ : and what do you look at then? If you?

T: und wohin gucken Sie da? wenn Sie?

P: To the floor, (.) usually

P: aufn Bode, (.) in der Regel

T: you look from the outside thus outside [you look?

T: von draußen also draußen gucken [Sie? 
through the door or so $<<$ [or (.) in front of the door after all
$P$ : [nee von dri >>also i geh scho in die Tür hinei
oder so $<<$ [oder (.)vor der Tür eben
$\mathrm{T}: \quad[\mathrm{hm} \quad \mathrm{hm}$
T: $\quad[\mathrm{hm} \quad \mathrm{hm}$
$\mathrm{P}$ : this now is quite a concrete thing
$P$ : dis wär jetz a ganz konkrete Sache
$\mathrm{T}: \uparrow \mathrm{hm} \mathrm{hm}$

Once again the therapist makes sure if he has correctly understood his conversation partner "if you enter through the front [door", again the patient answers by the irritating, contradicting image "Yes when I leave it is not". The way of agreeing by saying "yes" must make the therapist believe that the obsessive-compulsive symptom appears when entering through the door, the then following part leaves it open if "not" is meant as a $\operatorname{tag}^{7}$ or a denial.

This "game" is continued, the therapist asks about the direction: "you look from the outside thus outside [you look?", in the context of which also here it stays unclear if the view is imagined from the outside or to the outside. Once again, the patient reacts to this vagueness by a new perspective "you know I really enter through the door", thus repeatedly triggering an irritation due to his new point of view "in front of the door after all". The summarising remark "this now is quite a concrete thing" sounds almost ironic, and the therapist seems to answer this unintendedly unclear "concrete thing" by his highpitched double "hm hm".

Such examples are not a rarity during therapeutic conversation, but to our knowledge they are as yet unanalysed. This is a mild example of emphatic blinding, for the therapist it is made so to speak lastingly difficult to understand the architecture of the situation when the patient's obsessive-compulsory symptom appears. In a comprehensive way, the therapist cannot "see" what happens; his efforts to receive information by help of "ancillary questions" (Heritage 2011) are rejected in quite an everyday-practical sense here by a lack of empathy from the patient's side; this is where the therapist gives up and postpones his need of further explanation to a later moment.

Here we would like to go on by a much more drastic example of a "communicative flashbang" from our study on criminal sexual offenders (Buchholz, Lamott and Mörtl 2008), to illustrate this way how in therapy situations sometimes things happen for which Heritage's scheme (2011) is insufficient.

\footnotetext{
7 The term "tag" is used by conversation analysis for those "sweet little nothings" by way of which agreement is demanded during a conversation; other examples are "gell?", "ne" in German, "isn't it" in English, "oder" in Swiss German etc. (see Jefferson 2012). Translator's remark: the patient speaks a Bavarian dialect, saying "net” which here is translated by ,not”. Other than in English, in the Bavarian dialect "net" may as well mean something like "innit".
} 
The sexual offenders of our study were admitted for a social-therapeutic ward in prison, after their prospects having been judged as being sufficiently promising. There they participated in a completely video-recorded group therapy (for details see Buchholz et al. 2008). The therapists encouraged the participants a. o. to unfold the narratives of their offences, that is to tell about the offences for which they had been sentenced to prison. The example gives a conversation following such a story; one group member, Sepp, asks the one who has told his story, Otto, a question which refers to the narration of his offence. This narration has produced the information that the narrator, Otto, has been banned from making contact to his son.

Sepp B.: I would like to know - that thing about your son. Why are you allowed to see him only after he has turned 18 ? Or Sepp

B.: Mich würde interessieren - mit deinem Sohn. Warum darfst du den erst, wenn er 18 ist, sehen? Oder

(.)

Otto O.: Because it happened with my son=

Otto O.: Weil es passiert ist mit meinem Sohn=

Therapist K.: =What happened?

Therapeut K.: =Was is passiert?

(1)

Otto O.: After I well had abused him [once. Although it is not=

Otto O.: Seit ich ihn mal äh

missbraucht [habe missbraucht habe (.) Obwohl es nicht

Therapist K.: $\quad$ [pardon?=

Therapeut K.: [Bitte?

Otto O.: = true (-) He was only present.

Otto O.: stimmt (-) Er war nur dabei gewesen.

Therapist K: He was present?

Therapeut K.: Er war dabei?

Otto O.: He was present.

Otto O.: Er war dabei gewesen.

Therapist K.: Present

Therapeut K.: Dabei gewesen

Otto O.: All right, I will tell you once again how it happened with my son. We:ll:: Otto

O.: Gut, ich erzähle noch einmal wie es passiert ist mit meinem Sohn. A:lso::

Therapist K.: This is perhaps important after all.

Therapeut K.: Das ist ja vielleicht auch wichtig.

Sepp's question about the narration indicates (Heritage 2011, 2012, 2013) that his knowledge status is $\mathrm{K}-$ ( $\mathrm{K}$ minus); by this question he shows that there is something he has not yet understood or does not know. To such a question we would expect a piece of information which balances the mutual knowledge in such a way as to equal the inquirer's knowledge to Otto 's. Such as a statement like: "because the court has banned me from him" or something like that. However, there is a break after the break following Otto's "or", and starting by "because" he gives an explanation which, by the formulation "because it happened" immediately negates his own actor's competence and 
responsibility. The therapist reacts to this by quickly stepping in, and now Otto changes to a design, which accepts his own competence as an actor. It had been him, he admits, who abused his son. This way the reason why he is banned from seeing his son is at least hinted at.

Let us stop here for a moment. Otto answers Sepp's question by way of a kind of categorising activity, which rather refers to himself than to changing the inquirer's knowledge status. By the same move he refers to himself as a non-actor; he starts a complex transformation of his own position within the legal agenda: he changes from being an offender to being a witness. It is this irritation, we may assume, to which the therapist reacts by his overlapping "pardon?", and Otto answers as if the therapist had not listened. He repeats the last part of his speech and adds that "it is not true". His son had "only been present". If one listens to children, for example when they are saying "Now you are the robber", one may clearly observe their categorisation activities. The other is categorised as a "robber", however only "for fun". The category of fun is indicated by "now" - just leave it out, and you will at once note the difference.

In Otto's case one can leave out the word "only" - then his sentence is completely trivial: we may assume that somebody was present when being abused. What is the burden this "only" bears? "Only" indicates a change of the son's status, also he changes from being victim to being a witness who was "only present", and the way of having been present is transformed into being a somewhat coincidental witness. This transformation of position is called "footing" since Goffmann; one so to speak "has a different relation" to each other (Goodwin 2007). This kind of analysis might explain the way in which the therapist joins now. He reformulates "He was present?" and these three words are conversationally somewhat switched; three times in a row question and answer are exchanged without any change of content.

This leads to a particular effect. By way of this complex conversational operation Otto takes the speaker position of a witness, whereas previously Sepp has addressed him as a perpetrator. And there is more: the therapist confirms Otto's position as a witness and retreats to the position of a listener.

If one discusses scenarios of this kind with other therapists, not seldom they shake their head and wonder why the therapist did not take notice of this. However, one may be assured that such things happen several times a day to anybody working in the field of therapy; then it may be that we speak of an attack on thinking or on connections. To our knowledge it has as yet not been analysed how (by asking about the way) such attacks happen exactly. If it is typical for them that as a participant in such a conversation one does not notice them, one will not notice them. At least not as long as one has no transcripts at hand for an analysis but must rely on one's own memory for minutes which are sometimes taken down after a long day of practical work. However, it is these ways of confusing categories, which powerfully devaluates the hermeneutics of therapy. Theory calls this an "attack on thinking" (Bion 1963). This is a description of the function. A kind of behaviour we are not aware of as well as defence manoeuvres are conversationally staged, which way understanding, hermeneutics-based possibilities to answer are literally blinded. But it is not that this behaviour we are unaware of must always be worked out by way of analysis; our example shows in detail that it appears both at the visible and audible surface of the conversation if only we look at the details closely enough (Buchholz 2011). 


\section{Concluding Remark}

The selection of sequences has been purposefully restricted to those where violence can be observed within the context of speech interaction. Here it is less about damage caused by violating the boundaries of the private sphere but about subtleties of the therapeutic conversation for which the negotiation of closeness and distance, the roles of "leading and following" and the shaping of a professional relationship are essential. Both therapist and patient move within a conversational field within which they mutually influence each other's position. Irritations are created by incongruent conversational hints, e. g. by rising intonation indicating that one is going to continue, to be followed, however, by a very long break which again signals that it is the other's turn. On the one hand, such linguistic subtleties depict the shaping of the relationship, on the other hand a certain atmosphere of the relationship climate is only established this way. The corrections made in the context of such interactions may allow for new relationship experiences and, depending on the way in which they are solved, support or weaken the therapeutic relationship.

Intentions and attitudes are mutually investigated and communicated, in the context of which a common foundation of empathy may develop on whose basis interactiveconversational acts of violence can be balanced, which on the one hand influence this foundation and are on the other hand based on it, as it could be demonstrated by the example of Amalie and the rupture-repair cycle. In which way these conversations influence process and outcome of therapy must be analysed by future research. Also those communicative "blindings" may be supposed to be of significance which have not yet been analysed when it comes to the process of therapy. They are more than "face work" in the sense Goffman (1955) introduced the term. Face work means defensive maneuvers securing one's own status against dangers aof being blamed. "Blindings", and in the strong form of communicative "flashbangs" are violent act directed to others and thus, they damage. In therapeutic process they have not yet achieved necessary attention. Here answers will to be created that cross over an understanding of therapy as a hermeneutic act. The fine-grained conversation analysis makes visible, what in therapeutic discourse is more hidden under too global concepts like transferencecountertransference, resistance, attack on thinking, projective identification etc. Althoug we started from rough examples, our examples show the "pull of hostility" (Lippe et al. 2008). They demonstrate how complex the tightrope walk between autonomy-sensitive confrontation and verbal infringement is. The theme should be released from all scandalization. How a patient's violence by an extremely skillfull therapist can be handled shows the example of Amalia; the therapist arrives in a kind of tender tone, unexpected by the patient. That "blindings" on the other hand can actively obstruct empathy so deeply desired could be shown by other examples.

\section{Biographical Note}

Michael B. Buchholz is a psychologist and social scientist, full professor at "International Psychoanalytic University" (IPU), Berlin, Germany.

Marie-Luise Alder, psychologist, is research assistant in a project on "co-production of empathy in psychotherapy process research (CEMPP)", IPU. 


\section{References}

Aho, J. (2013). Randall Collins: Violence: A micro-sociological theory (Book review). Human Studies, 36, 149-151.

Anderson, C. A., \& Bushman, B. J. (2002). Human aggression. Annual Review Psychology, 53, 27-51.

Benjamin, L. S. (1974). Structural analysis of social behavior (SASB). Psychological Review, 81, 392-425.

Bergmann, J. R. (1980). Interaktion und Exploration: Eine konversationsanalytische Studie zur sozialen Organisation der Eröffnungsphase von psychiatrischen Aufnahmegesprächen. Unpublished dissertation. Konstanz, Germany.

Bion, W. R. (1963). Eine Theorie des Denkens. Psyche - Z Psychoanal, 17, 426-435.

Bourdieu, P. (1987). Sozialer Sinn. Kritik der theoretischen Vernunft. Frankfurt, Germany: Suhrkamp.

Bourdieu, P. (1990). Was heißt Sprechen? Mit einer Einführung von John B. Thompson. Wien, Austria: Braumüller-Verlag.

Braten, S. (2007). Introducing the matrix and multiple layers of intersubjectivity and empathy. In S. Braten (Ed.), On being moved. From mirror neurons to empathy (v. 68, pp. 1-21). Amsterdam, The Netherlands: John Benjamins.

Braten, S. (2009). The intersubjective mirror in infant learning and evolution of speech. Advances in consciousness research. Amsterdam, The Netherlands: John Benjamins.

Breithaupt, F. (2009). Kulturen der Empathie. Frankfurt, Germany: Suhrkamp.

Breyer, T. (Ed.). (2013). Grenzen der Empathie. Philosophische, psychologische und anthropologische Perspektiven. München, Germany: Wilhelm Fink Verlag.

Buchholz, M. B. (1993). Metaphern in der 'talking-cure' - die Rhetorik der 'Arbeit am Widerstand'. In M. B. Buchholz (Ed.), Metaphernanalyse (pp. 171-208). Göttingen, Germany: Vandenhoeck \& Ruprecht.

Buchholz, M. B. (1993). Supervision in (de-)konstruktivistischer Absicht. In M. B. Buchholz (Ed.), Metaphernanalyse (pp. 121-152). Göttingen, Germany: Vandenhoeck \& Ruprecht.

Buchholz, M. B. (1996/2003). Metaphern der 'Kur'. Qualitative Studien zum therapeutischen Prozeß. Giessen, Germany: Psychosozial-Verlag.

Buchholz, M. B. (2011). Körper - Bild - Szene - Geste - Sprechen. Wie alles zwangslos auseinander hervorgeht. Analytische Kinder- und Jugendlichen-Psychotherapie, 42, 7-35.

Buchholz, M. B. (2012). KANAMA - Integration von Konversations-, Narrations- und Metaphernanalyse: Ein Beitrag zur qualitativen Erforschung therapeutischer Gespräche. In M. Ochs \& J. Schweitzer (Eds.), Handbuch Forschung für Systemiker (pp. 215-240). Göttingen, Germany: Vandenhoeck \& Ruprecht.

Buchholz, M. B. (2012). Mikroprozesse therapeutischer Interaktion studieren! Folgerungen aus Outcome- und Prozessforschung für die professionelle Praxis der Psychoanalyse. In B. Boothe \& P. Schneider (Eds.), Die Psychoanalyse und ihre Bildung. Zürich, Switzerland: Sphères (Reihe Sphèreessays).

Buchholz, M. B. (2014). Patterns of empathy as embodied practice in clinical conversation - a musical dimension. Frontiers in Psychology, 5. doi:10.3389/fpsyg.2014.00349

Buchholz, M. B. (2014). Die dunkle Seite der Bindungsmetapher. Vorüberlegungen zu Täter-Opfer-Beziehungen aus der Konversationsanalyse. In C. E. Scheidt, G. Lucius-Hoene, A. Stukenbrock, \& E. Waller (Eds.), Narrative Bewältigung von Trauma und Verlust (pp. 135-149). Stuttgart, Germany: Schattauer.

Language and Psychoanalysis, 2015, 4 (2), 4-33

http://dx.doi.org/10.7565/landp.2015.007 
Buchholz, M. B. (2014). Die Feinheiten therapeutischen Sprechens.

Konversationsanalyse eines psychoanalytischen Erstgesprächs. In I. Bozetti, I.

Focke, \& I. Hahn (Eds.), Unerhört - Vom Hören und Verstehen. Die

Wiederentdeckung der grundlegenden Methoden der Psychoanalyse (pp. 219-240).

Stuttgart, Germany: Klett-Cotta.

Buchholz, M. B. (2014). Embodiment. Konvergenzen von Kognitionsforschung und analytischer Entwicklungspsychologie. Forum der Psychoanalyse, 30, 109-125.

Buchholz, M. B., \& Gödde, G. (2013). Balance, Rhythmus, Resonanz: Auf dem Weg zu einer Komplementarität zwischen "vertikaler" und "resonanter" Dimension des Unbewussten. Psyche - Z Psychoanal, 67, 844-880.

Buchholz, M. B., Lamott, F., \& Mörtl, K. (2008). Tat-Sachen. Narrative von Sexualstraftätern. Giessen, Germany: Psychosozial-Verlag.

Buchholz, M. B., \& Reich, U. (2015). Dancing Insight. How a Psychotherapist uses Change of Positioning in Order to Complement Split-Off Areas of Experience. Chaos and Complexity Letters, 8, 121-146.

Buchholz, M. B., Spiekermann, J., \& Kächele, H. (2015). Rhythm and Blues - Amalie's 152nd session. From Psychoanalysis to Conversation and Metaphor Analysis - and back again. International Journal of Psychoanalysis, 96, 877-910.

Bushman, B. J., \& Anderson, C. A. (2001). Is It Time to Pull the Plug on the Hostile versus Instrumental Aggression Dichotomy? Psychological Review, 108, 273-279.

Clayman, S. E. (2013). Turn-Constructional Units and the Transition-Relevance Place. In J. Sidnell \& T. Stivers (Eds.), The handbook of conversation analysis (pp. 150167). Chichester, UK: Wiley-Blackwell.

Collins, R. (2008). Violence - A Micro-Sociological Theory. Princeton, NJ: Princeton University Press.

Collins, R. (2009). The micro-sociology of violence. The British Journal of Sociology, $60,566-576$.

Collins, R. (2013). Entering and leaving the tunnel of violence: Micro-sociological dynamics of emotional entrainment in violent interactions. Current Sociology, 61, 132-151. doi:10.1177/0011392112456500

Corrin, J. (2010). Hm? What? Maternal repair and early child talk. In H. Gardner \& M. A. Forrester (Eds.), Analysing interactions in childhood. Insights from conversation analysis (pp. 23-42). Chichester, UK: Wiley-Blackwell.

Couper-Kuhlen, E. (2012). Exploring Affiliation in the Reception of Conversational Complaint Stories. In A. Peräkylä \& M.-L. Sorjonen (Eds.), Emotion in interaction (pp. 113-146). New York: Oxford University Press.

Dausendschön-Gay, U., \& Krafft, U. (2002). Text und Körpergesten. Beobachtungen zur holistischen Organisation der Kommunikation. Psychotherapie and Sozialwissenschaft, 4, 30-60.

Deppermann, A. (2011). The Study of Formulations as a Key to an Interactional Semantics. Human Studies, 34, 115-128.

Deppermann, A., \& Lucius-Hoene, G. (2008). Positionierung als Verfahren der Interaktionskontrolle. Thematisierung, De-Thematisierung und symbolische Aufhebung des Abschieds in der letzten Stunde der Therapie "Amalie". Psychotherapy and Sozialwissenschaft, 10, 21-39.

Deutsch, M. (1958). Trust and Suspicion. The Journal of Conflict Resolution, 2, 265-279.

Di Paolo, E. A., Rohde, M., \& Jaegher, H. de. (2011). Horizons for the Enactive Mind: Values, Social Interaction, and Play. In J. R. Stewart, O. Gapenne, \& E. A. Di Paolo (Eds.), Enaction. Toward a new paradigm for cognitive science (pp. 33-89). Cambridge, MA: MIT Press. 
Egbert, M. M., Golato, A., \& Robinson, J. D. (2009). Repairing reference. In J. Sidnell (Ed.), Conversation analysis - Comparative perspectives (pp. 104-132). Cambridge: Cambridge University Press.

Emde, R. N. (1988). The effect of relationships on relationships: a developmental approach to clinical intervention. In R. A. Hinde \& J. Stevenson-Hinde (Eds.), Relationships within Families. Mutual Influences. Oxford, UK: Clarendon Press.

Erhardt, I., Levy, R. A., Ablon, S. J., Ackerman, J. A., Seybert, C., Voßhagen, I., \& Kächele, H. (2014). Amalie Xs Musterstunde. Analysiert mit dem Psychotherapie Prozess Q-Set. Forum der Psychoanalyse, 30, 441-458.

Ferrari, P. F., \& Gallese, V. (2007). Mirror neurons and intersubjectivity. In S. Braten (Ed.), On being moved. From mirror neurons to empathy (v. 68, pp. 73-89). Amsterdam, The Netherlands: John Benjamins.

Franke, E. (2008). Raum - Bewegung - Rhythmus. Zu den Grundlagen einer Erkenntnis durch den Körper. In F. Bockrath, B. Boschert, \& E. Franke (Eds.), Körperliche Erkenntnis. Formen reflexiver Erkenntnis (pp. 15-40). Bielefeld, Germany: Transcript.

Frankel, Z., Levitt, H. M., Murray, D. M., Greenberg, L. S., \& Angus, L. E. (2006). Assessing silent processes in psychotherapy: an empirical derived categorization system and sampling strategy. Psychotherapy Research, 16, 627-638.

Frei, M., Michel, K., \& Valach, L. (2012). Humorvolle Taktlosigkeit, Kreditierung interaktiv: ein gesprächsanalytischer Werkstattbericht. Psychoanalyse - Texte zur Sozialforschung, 16, 458-471.

Frei, M., Michel, K., \& Valach, L. (2012). Humorvolle Taktlosigkeit, Kreditierung interaktiv: ein gesprächsanalytischer Werkstattbericht. Psychoanalyse - Texte zur Sozialforschung, 16, 458-471.

Freud, S. (1916). Vorlesungen zur Einführung in die Psychoanalyse. G.W., Bd. 11. Frankfurt, Germany: S. Fischer.

Gabbard, G. O. (1994). Psychotherapists who transgress sexual boundaries with patients. Bulletin of the Menninger Clinic, 58, 124-135.

Gallese, V., \& Goldman, A. I. (1998). Mirror neurons and the simulation theory of mindreading. Trends in Cognitive Sciences, 2, 493-501.

Goffman, E. (1955). On face work. Psychiatry, 18, 213-231.

Goffman, E. (1978). Response Cries. Language, 54, 787-815.

Goodwin, C. (2000). Die Ko-Konstruktion von Bedeutung in Gesprächen mit einem Aphasiker. Psychotherapie and Sozialwissenschaft, 2, 224-246.

Goldman, A. I. (2006). Simulating Minds. The Philosophy, Psychology, and Neuroscience of Mindreading. Oxford, UK: Oxford University Press.

Goodwin, C. (2007). Interactive Footing. In E. Holt \& R. Clift (Eds.), Reporting Talk. Reported Speech in Interaction (pp. 16-45). Cambridge, UK: Cambridge University Press.

Goodwin, C. (2012). Zeigegesten und kollaborative Bedeutungskonstitution in der Interaktion mit Aphasikern. In R. Ayaß \& C. Meyer (Eds.), Sozialität in Slow Motion. Theoretische und empirische Perspektiven; Festschrift für Jörg Bergmann (pp. 405-419). Wiesbaden, Germany: Springer.

Greenspan, S. I., \& Shanker, S. G. (2007). Der erste Gedanke. Frühkindliche Kommunikation und die Evolution menschlichen Denkens. Weinheim, Germany: Beltz-Verlag.

Grice, P. (1975). Logic and conversation. In P. Cole \& J. L. Moran (Eds.), Syntax and semantics III: Speech acts. New York, NY: Academic Press. 
Gumbrecht, H. U. (1995). Zwei Schlaglichter. Merkur, 49, 131-144. Originally published in 1926)

Hepburn, A., \& Bolden, G. B. (2013). The Conversation Analytic Approach to Transcription. In J. Sidnell \& T. Stivers (Eds.), The handbook of conversation analysis (pp. 57-77). Chichester, UK: Wiley-Blackwell.

Heritage, J. (2011). The interaction order and clinical practice: Some observations on dysfunctions and action steps. Patient Education and Counseling, 84, 338-343. doi:10.1016/j.pec.2011.05.022

Heritage, J. (2007). Intersubjectivity and progressivity in person (and place) reference. In N. J. Enfield \& T. Stivers (Eds.), Person reference in interaction. Linguistic, cultural, and social perspectives (pp. 255-280). Cambridge, UK: Cambridge University Press.

Heritage, J. (2011). Territories of knowledge, territories of experience: empathic moments in interaction. In T. Stivers, L. Mondada, \& J. Steensig (Eds.), The morality of knowledge in conversation (pp. 159-183). Cambridge, UK: Cambridge University Press.

Heritage, J. (2012). Epistemics in Action: Action Formation and Territories of Knowledge. Research on Language \& Social Interaction, 45, 1-29.

Heritage, J. (2013). Epistemics in Conversation. In J. Sidnell \& T. Stivers (Eds.), The handbook of conversation analysis (pp. 370-395). Chichester, UK: WileyBlackwell.

Heschen, C., \& Schegloff, E. A. (2003). Aphasic Agrammatism as Interactional Artifact and Achievement. In C. Goodwin (Ed.), Conversation and brain damage (pp. 231283). Oxford, UK: Oxford University Press.

Hitzler, S. (2013). Recipient Design in institutioneller Mehrparteieninteraktion. Gesprächsforschung - Online-Zeitschrift zur verbalen Interaktion, 14, 110-132.

Jakobson, R. (1955). Aphasia as a linguistic problem. In H. Werner (Ed.), On expressive language. Worcester, MA: Clark University Press.

Jefferson, G. (2012). Das grausige Ne? Eine Untersuchung des Strebens nach Antwort nach der Antwort. In R. Ayaß \& C. Meyer (Eds.), Sozialität in Slow Motion. Theoretische und empirische Perspektiven; Festschrift für Jörg Bergmann (pp. 299-333). Wiesbaden, Germany: Springer.

Kächele, H., Albani, C., Buchheim, A., Hölzer, M., Hohage, R., Mergenthaler, E.,. . . Thomä, H. (2006). The German specimen case, Amalia X: Empirical studies. International Journal of Psychoanalysis, 87, 809-826. doi:10.1516/17NN-M9HJU25A-YUU5

Kächele, H., \& Thomä, H. (2003). Amalie X - Der Verlauf einer psychoanalytischen Therapie. In G. Poscheschnik, R. Ernst, \& Klagenfurter Mittwoch-Gesellschaft (Eds.), Psychoanalyse im Spannungsfeld von Humanwissenschaft, Therapie und Kulturtheorie. Frankfurt, Germany: Brandes \& Apsel.

Kitzinger, C. (2013). Repair. In J. Sidnell \& T. Stivers (Eds.), The handbook of conversation analysis (pp. 229-257). Chichester, UK: Wiley-Blackwell.

Krämer, S. (2007). Sprache als Gewalt oder: Warum verletzen Worte? In S. K. Herrmann, S. Krämer, \& H. Kuch (Eds.), Verletzende Worte. Die Grammatik sprachlicher Missachtung (pp. 31-48). Bielefeld: transcript.

Kupetz, M. (2013). Verstehensdokumentation in Reaktionen auf Affektdarstellungen am Beispiel von 'das glaub ich'. Deutsche Sprache, 13(1), 72-96.

Lakoff, G., \& Johnson, M. (1998). Leben in Metaphern - Konstruktion und Gebrauch von Sprachbildern (engl. 1980). Mit einem Vorwort von Michael B. Buchholz. Heidelberg: Carl Auer. 
Levinson, S. C. (2006). On the Human “Interaction Engine”. In S. C. Levinson \& N. J. Enfield (Eds.), Wenner-Gren Center International symposium series. Roots of human sociality. Culture, cognition and interaction (pp. 39-69). Oxford: Berg Publishers.

Lippe, A. L. von der, Monsen, J. T., Ronnestad, M. H., \& Eilertsein, E. (2008). Treatment failure in psychotherapy: The pull of hostility. Psychotherapy Research, 18(4), 420432.

Levinson, S. C., \& Enfield, N. J. (Eds.). (2006). Wenner-Gren Center International symposium series. Roots of human sociality. Culture, cognition and interaction. Oxford: Berg Publishers.

Martinez, C., Tomicic, A., \& Medina, L. (2012). Dialogical Discourse Analysis of Psychotherapeutic Dialogue: Microanalysis of Relevant Psychotherapeutic Eipisodes. International Journal for Dialogical Science, 6(1), 99-121.

Mayer, A. (2013). Grenzen der Empathie im Angesicht von Opazität. In T. Breyer (Ed.), Übergänge: Vol. 63. Grenzen der Empathie. Philosophische, psychologische und anthropologische Perspektiven (pp. 109-136). München: Wilhelm Fink Verlag.

Mazur, A. (2009). A Hormonal Interpretation of Collin's Micro-sociological Theory of Violence. Journal for the Theory of Social Behavior, 39(4), 434-447.

Mead, G. H. (1973). Geist, Identität und Gesellschaft (1934). Frankfurt/M.: Suhrkamp.

Mellies, R., \& Winnecken, A. (1990). Aphasie und Emotion. In K. Ehlich, A. Koerfer, A. Redder, \& R. Weingarten (Eds.), Medizinische und therapeutische Kommunikation. Opladen: Westdeutscher Verlag.

Menary, R. (Ed.). (2010). Life and mind. The extended mind. Cambridge, MA: MIT Press.

Mergenthaler, E., \& Kächele, H. (1988). The Ulm Textbank Management System: A Tool for Psychotherapy Research. In H. Dahl, H. Kächele, \& H. Thomä (Eds.), Psychoanalytic Process Research Strategies. Berlin, Germany: Springer.

Peräkylä, A. (2004). Making Links in Psychoanalytic Interpretations: A Conversation Analytical Perspective. Psychotherapy Research, 14, 289-307.

Peräkylä, A. (2013). Conversation Analysis in Psychotherapy. In J. Sidnell \& T. Stivers (Eds.), The handbook of conversation analysis (pp. 551-575). Chichester, UK: Wiley-Blackwell.

Peräkylä, A., Antaki, C., Vehviläinen, S., \& Leudar, I. (Eds.). (2008). Conversation analysis and psychotherapy. Cambridge, UK: Cambridge University Press.

Pfänder, S., \& Gülich, E. (2013). Zur interaktiven Konstitution von Empathie im Gesprächsverlauf. Ein Beitrag aus der Sicht der linguistischen Gesprächsforschung. In T. Breyer (Ed.), Grenzen der Empathie. Philosophische, psychologische und anthropologische Perspektiven (pp. 433-458). München, Germany: Wilhelm Fink Verlag.

Sacks, H., Schegloff, E. A., \& Jefferson, G. (1974). A simplest systematics for the organization of turn-taking for conversation. Language, 50, 696-735.

Salgado, J., Cunha, C., \& Bento, t. (2013). Positioning Microanalysis: Studying the Self through the Exploration of Dialogical Processes. Integrative Psychological \& Behavioral Science, 47, 143-161.

Scarvaglieri, C. (2013). "Nichts anderes als ein Austausch von Worten": Sprachliches Handeln in der Psychotherapie. Reihe Germanistische Linguistik: Vol. 298. Berlin, Germany: De Gruyter.

Schegloff, E. A. (1987). Between Macro and Micro: Contexts and other Connections. In J. C. Alexander, B. Giesen, R. Münch, \& N. J. Smelser (Eds.), The micro-macro link (pp. 207-236). Berkeley, CA: University of California Press. 
Schlicht, T. (2013). Mittendrin statt nur dabei: Wie funktioniert Kognition? In T. Breyer (Ed.), Grenzen der Empathie. Philosophische, psychologische und anthropologische Perspektiven (pp. 45-92). München, Germany: Wilhelm Fink Verlag.

Schütz, A. (1932). 'Um-zu'- und 'Weil'-Motive. In H. Steinert (Ed.), Symbolische Interaktion. Arbeiten zu einer reflexiven Soziologie. Stuttgart, Germany: KlettCotta.

Shapiro, L. A. (2011). Embodied cognition. New Problems of Philosophy. London, UK: Routledge.

Sidnell, J. (2007). Repairing person reference in a small Caribbean commuity. In N. J. Enfield \& T. Stivers (Eds.), Person reference in interaction. Linguistic, cultural, and social perspectives (pp. 281-308). Cambridge, UK: Cambridge University Press.

Sidnell, J., \& Stivers, T. (Eds.). (2013). The handbook of conversation analysis. Chichester, UK: Wiley-Blackwell.

Stivers, T., Enfield, N. J., Brown, P., Englert, C., Hayashi, M., Heinemann, T.,. . . Levinson, S. C. (2009). Universals and cultural variation in turn-taking in conversation. Proceedings of the National Academy of Sciences, 106, 10587-10592. doi:10.1073/pnas.0903616106

Streeck, J. (2012). Nachhaltige Angst. In R. Ayaß \& C. Meyer (Eds.), Sozialität in Slow Motion. Theoretische und empirische Perspektiven; Festschrift für Jörg Bergmann (pp. 447-462). Wiesbaden: Springer.

Streeck, J., Goodwin, C., \& LeBaron, C. D. (Eds.). (2011). Learning in doing: social, cognitive and computational perspectives. Embodied interaction: Language and body in the material world. New York, UK: Cambridge University Press.

Streeck, U. (2001). 'Ja, genau, genau'. Bestätigungen als Versuche des Patienten, die Kompetenz des Psychotherapeuten als eigene zu deklarieren - eine gesprächsanalytische Untersuchung. Psychotherapy and Sozialwissenschaft Heft, 3, 74-94.

Stueber, K. R. (2006). Rediscovering Empathy. Agency, Folk Psychology, and the Human Sciences. Cambridge, UK: MIT Press.

Thomä, H., \& Kächele, H. (1985). Lehrbuch der psychoanalytischen Therapie. Bd. 1. Berlin, Germany: Springer.

Tress, W., Henry, W. P., \& Strupp, H. H. (1990). Die Strukturanalyse sozialen Verhaltens (SASB) in Ausbildung und Forschung. Ein Beitrag zur 'funktionellen Histologie' des psychotherapeutischen Prozesses. Zeitschrift für psychosomatische Medizin, 36, 240-257.

Tschacher, W., Tomicic, A., Martinez, C., \& Ramseyer, F. (2012). Formen der Synchronie in dyadischer Interaktion. In E. H. Witte \& S. Petersen (Eds.), Sozialpsychologie, Psychotherapie und Gesundheit (pp. 38-57). Lengerich, Germany: Pabst Science Publishers.

Vuust, P., Wallentin, M., Mouridsen, K., Ostergard, L., \& Roepstorff, A. (2011). Tapping polyrhythms in music activates language areas. Neuroscience Letters, 494, 211-216. 